AUTHOR MANUSCRIPT VERSION

Kofi Yakpo*

\title{
"The only language we speak really well": the English creoles of Equatorial Guinea and West Africa at the intersection of language ideologies and language policies
}

DOI 10.1515/ijsl-2016-0010

Abstract: This article explores the nexus between language policies and language ideologies in Equatorial Guinea and West Africa. By analyzing spoken and written discourses in Spanish and Pichi, I identify a set of ideas and beliefs about Pichi and the semiotic processes by which they have emerged. The comparison of Pichi with Krio, Nigerian Pidgin, Cameroon Pidgin and Ghanaian Pidgin English shows that Pichi is the most disadvantaged of the West African English-lexicon creoles with respect to a number of sociolinguistic characteristics. I argue that linguistic ideologies about Pichi have contributed significantly to disregarding language policy options for elevating the status and extending the uses of Pichi in Equatorial Guinea. Pichi is nevertheless expected to expand its social functions by gradually conquering additional domains of use as has been the case with the other English creoles of West Africa.

Keywords: Africa, Spanish, creole, language ideology, discourse

\section{Introduction}

In the last half century or so, the string of related English-lexifier creoles and pidgins of Nigeria, Cameroon, Ghana, Sierra Leone and Equatorial Guinea have seen a spectacular expansion as first and second languages. Today, their combined speaker numbers total well over hundred million. These languages have, however, received very little or no attention from state institutions in the form of status or corpus planning, if their use has not been actively discouraged. One objective of this article is to show the position of Pichi (also referred to as Pichinglis, Pidgin [pijin], Pidgin English [pijin inglis], Pichin, and Krio by its speakers), the English creole of Equatorial Guinea in the country's linguistic ecology. A comparison of Pichi with Nigerian Pidgin, Cameroon Pidgin, and Krio

*Corresponding author: Kofi Yakpo, The University of Hong Kong, Hong Kong, E-mail: kofi@hku.hk 
(Sierra Leone) shows that Pichi is in the least favourable position with respect to a number of sociolinguistic characteristics. Despite being a vibrant home language and the second largest indigenous language of Equatorial Guinea, Pichi is largely absent from the public sphere, even from relatively unregulated domains like pop music. Other creole languages of West Africa also have to struggle with a low prestige, but contrary to Pichi, these languages have in recent decades been steadily conquering additional domains of use. The specificity of Pichi in this regard partly reflects a general absence of an organized state response to linguistic diversity in Equatorial Guinea - the country is characterized by a consistent "exoglossic" language policy that relies exclusively on the use of the colonial language Spanish in official functions. Beyond that, the low visibility of Pichi in the public sphere is also a concomitant of language ideologies that place negative values on Pichi. A second objective of this article is to identify and characterize aspects of these ideologies by looking at written and spoken discourse, including testimonies in Pichi, thereby linking language ideologies to the weak position of Pichi in the linguistic scenario of Equatorial Guinea. This article is the first work to look at the intersection of language policy and language ideologies in Equatorial Guinea and to present a comparative overview of some important sociolinguistic features of the English-lexifier creoles of West Africa.

The structure of this article is as follows. In Section 2, I address terminological and theoretical issues and in Section 3, I provide information on the data and methodology. In the main part in Section 4, I describe the position of Pichi in the linguistic ecology of Equatorial Guinea. In the same section, I go on to analyze discourses about Pichi in order to identify language ideologies vis-à-vis Pichi and the conceptual schemes that underlie them. In Section 5, I compare selected sociolinguistic characteristics of Pichi relating to the speaker community, use domains and language policies with those of the four largest Englishlexicon creoles of West Africa, namely Nigerian Pidgin, Cameroon Pidgin, Krio (Sierra Leone), and Ghanaian Pidgin English. Section 6 concludes this article.

\section{Language policies and language ideologies}

In this section, I provide a brief explanation of my use of the concepts of "language policies", "language ideologies" and other relevant terms. Skutnabb-Kangas et al. (1994: 79-80) propose a typology of language policies along various axes. One of these concerns the degree of overtness versus covertness, i. e. how much language policies are spelt out through legislation or in explicitly formulated policies. We will see that the English-lexicon creoles 
and pidgins of West Africa are only marginally, if at all, the subject of overt language policies.

Reh and Heine (1982) distinguish between "endoglossic" and "exoglossic" language policies, i. e. involving the use of an indigenous language versus the use of a non-indigenous (usually colonial) language in official functions. This distinction is relevant for the African continent where the vast majority of nations feature exoglossic policies, and the languages of the former colonizers have retained their official functions since independence (see the contributions in Baldauf and Kaplan [2004] and Baldauf and Kaplan [2007]). Many African constitutions with an exoglossic orientation nevertheless contain provisions that "recognize" and "promote" the indigenous African languages spoken in the territory. In African legislative terminology these recognized indigenous languages are generally referred to as "national languages". ${ }^{1}$ In most African constitutions the designation "national language" is however devoid of legal substance and consequence, because existing laws do not oblige the state to use African "national languages" in institutional functions.

I refer to "language ideologies" as the system of ideas, i. e. feelings, values, beliefs, about the relations between language and social structure (see Irvine 1989). More specifically, linguistic ideologies are the conceptual schemes that participants in a linguistic ecology will use and reproduce in order to "frame their understanding of linguistic varieties" and to "map those understandings onto people, events and activities" of relevance to them (Irvine and Gal 2000: 35). I include the analysis of language ideologies because I will claim that ideologies impact directly on the formulation and implementation of language policies. Language ideologies crucially provide the authority on which political action with respect to "languages" (in the sense of "lects", comprising "languages", "varieties”, “registers”, “styles”) is argued, justified and enacted.

Gal and Irvine (1995) and Irvine and Gal (2000) identify three semiotic processes by which participants in a socio-linguistic setting construct a shared cognitive-affective framework to identify, evaluate and represent linguistic difference and variation. "Iconiziation" is the process by which linguistic features

1 National constitutions are not normally included in the bibliography, because they widely available on the internet and in libraries (1995), Article 2, states that "the Republic of Gabon adopts French as its official working language, while "working for the protection and promotion of the national languages" ("La République gabonaise adopte le français comme langue officielle de travail. En outre elle oeuvre pour la protection et la promotion des langues nationales"). Article 2 of the Constitution of the Democratic Republic of Congo (2006) declares French the official language while the state "ensures the promotion" ("assure la promotion") of the four most widely spoken languages of the country Kikongo, Lingala, Swahili and Tshiluba. 
are mapped onto social images that index social groups and the activities performed by them. "Recursivity" describes the mimetic process of transferring a set of relations established at one level to another level. "Erasure" stands for the process by which facts inconsistent with the ideology are rendered invisible or insignificant. A discourse analysis of language ideologies about Pichi in Section 4.2 will show how these three interlocking semiotic processes produce particular representations of the language and its speakers.

Ideologies about language are, of course, not only shared by members of a particular "speech community", however imagined it may be. My own ideological positioning as a researcher is informed by the understanding that all "languages”, not only creoles like Pichi, are multilectal, fuzzy, continuously evolving and inherently unstable systems. This view is opposed to a long tradition of "exceptionalism" (DeGraff 2003) with ideological roots in colonialism, through which creoles have been reified, stripped of their communicative and socio-cultural context, and defined via the absence of particular features, thus constructing them as "simpler' and typologically and sociologically aberrant linguistic systems (see, for example, Coelho 1967; Whinnom 1971; Bickerton 1981, 1984; McWhorter 2001, 2005; Bakker et al. 2011).

One consequence of viewing creoles as full-fledged systems, and beyond that, as the norm of how linguistic systems function outside of the standardized universe (cf. Makoni and Pennycook 2007: 20-21), is that they are suitable subjects of endoglossic language policies. The implicit position that endoglossic, rather than exoglossic policies are in themselves a necessity for African nations like Equatorial Guinea is based on a substantial body of research in linguistics, education and political science, which supports the cognitive, socio-cultural and political-economic advantages of the use of indigenous languages in all social domains and institutional spheres (see, for example, Bamgbose 2000; BrockUtne 2001, 2003, 2010; Djité 2008; Kamwangamalu 2004; Muthwii and Kioko 2004; Mwinsheikhe 2002; Prah 2002; Ouane and Glanz 2010).

\section{The data}

The data on which this article relies was collected during field research in Equatorial Guinea, Nigeria and Ghana between 2003 and 2013. The Pichi corpus consists of about 50,000 words of conversations, narratives, and elicited speech that I recorded, transcribed and analyzed between 2003 and 2009. Until the publication of Yakpo (2009) and subsequent work (Yakpo 2010, 2012, 2013a, 2013b) next to nothing was known about the grammar of Pichi, and to my knowledge no other work has yet been done on sociolinguistic or other aspects of Pichi. The situation 
regarding Pichi is indicative of a general dearth of linguistic and usage-related data on the languages of Equatorial Guinea. It also reflects the yet relatively modest scientific output on the West African English-lexifier creoles in general, bearing speaker numbers of these languages in mind, and the variety of domains they are used in (see Section 5). The Pichi excerpts in Section 4.2 form part of informal metalinguistic conversations conducted in Pichi, involving three to four participants (see Yakpo [2009: 21-25] for a detailed description of the backgrounds of linguistic informants). I relied on sources found in the internet for outside perspectives on Pichi because I did not conduct systematic sociolinguistic interviews on language attitudes beyond the circle of my linguistic informants. Nevertheless I found the "etic" (outside) views on Pichi that transpire in these excerpts to reflect opinions I have heard reproduced and discussed in countless conversations over the years of research in Equatorial Guinea. I see these opinions, at the risk of sometimes appearing impressionistic, as faithful representations of existing language ideologies about Pichi, and as contributions to a better understanding of the Equatoguinean linguistic scenario.

\section{Language policy, language ideologies and language use in Equatorial Guinea}

In this section, I compare official language policies with language use in Equatorial Guinea. I conclude that there is a discrepancy between official approaches and the actual significance of particular languages for national and international communication and economic life. In this, the sociolinguistic setting of Equatorial Guinea is not fundamentally different from that of other countries in which English-lexifier creoles and pidgins are spoken (cf. Section 5). Equatorial Guinea however differs from other African countries in the degree to which it relies on the use of a non-indigenous, European language for official, administrative and public functions. In such a context, the creole language Pichi appears doubly disadvantaged, first as one among other African languages, and secondly as a creole, and therefore particularly exposed to views about its inferiority as a language in its own right. Such ideological aspects are covered in Section 4.2.

\subsection{Pichi in the linguistic ecology of Equatorial Guinea}

The constitution of Equatorial Guinea (Article 4) declares Spanish, French and Portuguese “official languages” while the "indigenous languages are recognized 
as an integral part of the national culture” National constitutions are not normally included in the bibliography, because they widely available on the internet and in libraries. Three European languages are therefore given legal recognition as languages of government business and officialdom. The term "recognition" reserved for the African languages of the country is however of no legal substance, since their use may not be claimed as a personal, group or territorial right before the courts of the country. From the primary to the tertiary levels, instruction is given alone in Spanish, which is de facto, the only official language of the country. There is no legally or politically defined role for education in the African mother-tongues of the majority of Equatoguinean children (cf. Yakpo 2011). However, the national education bill currently in vigour (República de Guinea Ecuatorial 2007) offers the optional use of indigenous languages in education (Olo Fernandes 2012: 4). In sum, Equatorial Guinea features an overtly exoglossic language policy that uniquely privileges the colonial language Spanish.

The political and legal context differs markedly from the realities of language use in Equatorial Guinea. First, neither of the co-official languages French and Portuguese are systematically used for official functions in Equatorial Guinea, nor do these two languages play any significant role for communication among Equatoguineans. ${ }^{2}$ Instead, two indigenous languages of Equatorial Guinea, namely Fang (in the continental part of the country) and Pichi (on Bioko island), serve as the most important home and vehicular languages in the country (see Lewis et al. [2013] for speaker numbers). A hundred years of forceful imposition of Spanish during colonial rule (see Bolekia Boleká 2005; Castillo Rodrîguez 2013), and another 50 years of continued state support for Spanish after independence have led to a certain degree of entrenchment and nativization of Spanish in Equatorial Guinea, and in Bioko in particular (Morgades Bessari 2004; Piedrafita 2009). Nonetheless, Pichi and Fang serve as the most important international languages to common Equatoguineans. Pichi has served as the the primary language of interaction for Equatoguineans in dealings with Nigerians, Cameroonians and Ghanaians since at least the beginning of the twentieth century

2 A report by the OIF (Organisation Internationale de la Francophonie 2010) lists 7 percent of Equatoguineans as "francophone" (which includes the ability to speak, read and write French) and 22 percent as "partially francophone" (which means being able to speak French). The OIF states that these figures were provided by the government of Equatorial Guinea in response to a questionnaire submitted by OIF. To my knowledge, no systematic national linguistic survey has so far been conducted in Equatorial Guinea, not even for individual languages. The country page of Equatorial Guinea on the OIF website (http://www.francophonie.org/GuineeEquatoriale.html) goes as far as declaring 200,000 Equatoguineans French speakers, hence nearly a quarter of the official population. Such inflationary figures must be seen to serve political purposes. 
(cf. Lipski 1992). Today, it is probably safe to assume that up to seventy percent of the population of Bioko island, hence well above 100,000 speakers regularly use Pichi at various levels of nativization and in various multilingual and multilectal constellations in and outside their homes (Yakpo 2013: 194). The speaker community of Pichi is ethnically and culturally diverse, and includes the traditional creole community of Bioko (the "Fernandinos", see Lynn [1984]), as well as ethnically mixed families of various constellations and large numbers of people who self-identify as ethnic Bube, but have shifted to Pichi as a primary language (referred to as "nuevos criollos" [New Creoles] by Morgades Bessari [2011]; see also Bolekia Boleká [2005]). Fang is the most widely spoken autochthonous language of Equatorial Guinea before Pichi. The language name is a cover term for a continuum of closely related, mutually intelligible lects used across Equatorial Guinea, Southern Cameroon, Gabon, and the border zone of The Republic of Congo (see Perrois [1972: 102-105] on the linguistic relations between these varieties).

No African language enjoys any form of explicit state support or legal entrenchment in Equatorial Guinea. That said, languages other than Pichi are nonetheless spontaneously produced in public discourse, are increasingly heard in semi-formal contexts, and have slots in the national radio station Radio Nacional de Guinea Ecuatorial. Some have more or less accepted standard orthographies, and there is a modest religious literature (e. g. Asociación Cristiana de Traducciones Biblicas n.d.). Pichi is, in contrast, absent from print, online and audio-visual media, and is not normally employed in church, larger social gatherings (e.g. weddings) or other semi-formal settings. Pichi is equally absent in contemporary pop music culture, a somewhat surprising fact in view of the prominence of music sung in Nigerian and Ghanaian Pidgin English in the soundscape of Malabo. ${ }^{3}$ Interactions in Pichi are therefore almost entirely relegated to the interpersonal domain. Finally, prior to the publication of Yakpo [2009a] and [2010], the only existing descriptive work available was a modest grammar sketch and wordlist by Zarco (1938) of limited usefulness today (see excerpt [1] below).

In Equatorial Guinea, as in other African countries, a complex conglomerate of political and economic factors, socio-cultural dependence on the former colonizer, elitism, a lack of political vision among the ruling elites, weak state institutions and the lack of resources, administrative and technical expertize seems to be responsible

3 The first Equatoguinean Hip Hop song rapped in Pichi that I am aware of is "mi tierra", officially released by the Equatoguinean Hip Hop pioneer Meko on his first album "Lo que dan los años (2009)" but he gave me a pre-release copy of the album already in 2007. In the song about the African émigré's plight in Spain, the use of Pichi allows the listener to empathize with the rapper's longing for home expressed in the song. 
for the neglect of African languages by state institutions, and the continuation of colonial language policies. However, explanations for the discrepancy between the near-total absence of Pichi in the public sphere and its importance as a vibrant community and vehicular language must also be sought in prevailing ideologies and attitudes about Pichi. I explore these in the following section.

\subsection{Language ideologies about Pichi}

The English-lexicon Creoles of Africa and the Americas were created by African and African-descended communities as adaptive and creative responses to the European slave trade, slavery, and colonialism. The dichotomizing epistemological order established by European colonialism (cf. Mudimbe 1988: 1-24), provided a fertile ground for European observers to construct creoles as insufficient linguistic systems. This legacy of othering of creole languages is only gradually being deconstructed in academia (see, for example, DeGraff [2003], the contributions in Plag [2003], Ansaldo et al. [2007], Faraclas and Klein [2009] and Aboh and Smith [2009]). Today these ideas linger on in the public and intellectual discourses in post-colonial creole-speaking nations (for the situation in the English creolespeaking Caribbean, cf. Devonish [1986, 2010] and cf. Schieffelin and Doucet [1994] for the situation in Haiti). The introductory chapter of the until recently only existing work on Pichi, a grammar sketch and vocabulary list (Zarco 1938) contains a pungent exposition of the colonialist perspective on creoles:

(1) Siendo tan reducido el caudal de términos del inglés africano por tratarse de una lengua tan imperfecta en comparación con las nuestras, no se puede hablar propiamente de Diccionario, sino de un simple Vocabulario [...].

'The vocabulary of African English is so reduced since it is such an imperfect language compared to ours [i.e. European languages], that one should rather see this work as a simple vocabulary list rather than a dictionary.'

(Zarco 1938: 107)

In the present, similar discourses are being produced that construct an image of inferiority of Pichi vis-à-vis English (the lexicon-providing language) and Spanish (the official and prestige language). Two topoi can be found in this regard in written and spoken discourses. The first topos revolves around the supposed substandardness of Pichi, the second is concerned with a perceived excessive hybridity of Pichi. The following quote from a contributor to an online discussion on Equatorial Guinea is characteristic for the substandardness topos. 
The "dialect" vs. "language" opposition is marshaled as a referential frame for opposing Pichi and Spanish, but it is also applied to the other African languages spoken in Equatorial Guinea. While Spanish is referred to as a language (idioma), Pichi and the other indigenous languages are regrouped under the heading of dialect (dialectos), hence substandard varieties, lacking the characteristics of full-scale languages:

(2) El idioma oficial de Guinea es el español, Guinea fue colonia española, y además del español lo que suelen hablar es en su dialecto "Pidgin” pero además creo que se hablan como 5 ó 6 dialectos más...

'The official language of Equatorial Guinea is Spanish, Guinea was a Spanish colony, and what they speak in addition to Spanish is their dialect "Pidgin", but additionally I think they speak around five to six other dialects...' (http://www.spaniards.es/foros/2009/11/16/trabajar-en-guinea)

The distinction between "dialect" and "language" is taken to its conclusion in the following excerpt, which underlines the status of Pichi as a rudimentary form of communication. The creole is constructed as a corrupted offshoot of English, a broken jargon, hence undeserving of the status of a full-fledged language:

(3) El pichinglis es una jerga dialectal guineana del inglés que incorpora palabras de las lenguas locales. Es una lingua franca de gramática muy rudimentaria y escaso vocabulario, que se parece a la manera de hablar de los jefes indios en las películas del Oeste.

'Pichinglis is a dialectal jargon of English spoken in Guinea that incorporates words from the local languages. It is a lingua franca with a very rudimentary grammar and a sparse vocabulary that resembles the way of speaking of Indian chiefs in Western Movies.'

(http://soc.culture.argentina.narkive.com/sNNPCFib/el-nuevo-reino-de-leon.)

An example for the second topos, excessive hybridity, can be found in excerpt (4) below. Pichi is referred to by the noun mezcolanza 'hotchpotch' rather than the less evaluative term mezcla 'mixture'. The underlying assumption is that Pichi with its supposedly mixed lexicon and a grammar unfamiliar to European observers, is excessively hybrid, a linguistic mongrel so to say:

(4) En Malabo (llevo ya semana y media en la escuela El Buen Pastor) el ritmo es otro, en una ciudad de ritmo africano (en todos los sentidos) y mezcla de 
bubis, fang, kombes, criollos y con el pidgin (esa mezcolanza de inglés con español y lenguas locales) como lengua tan común como el castellano.

'In Malabo (I've been at the El Buen Pastor school for one and a half weeks now) the rhythm is different, in a city of African rhythm (in every sense) and a mixture of Bubis, Fangs, Kombes, Creoles and with Pidgin (that hotchpotch of English, Spanish and local languages) being as common as Spanish.' (http://cronicasguineanas.blogspot.hk/2012_09_01_archive.html, accessed 2 April 2014)

The perceived anarchic and amorphous nature of Pichi is by extension seen as a threat to the acquisition and maintenance of (Iberian) Spanish in the country, as expressed in excerpt (5) below from an Equatoguinean scholar:

(5) El pichinglis especialmente representa una potente amenaza para la pureza de la lengua española, al mismo tiempo que es un gran suministrador de neologismos, lo cual contribuye al enriquecimiento del léxico español local y global.

'Pichinglis in particular, represents a serious threat to the purity of the Spanish language, while at the same time being an important provider of neologisms and thereby contributing to the enrichment of the Spanish lexicon locally and globally.'

(Djo Tiogang 2007: 337)

The view expressed by the Equatoguinean source in (5) above is, however, ambivalent in its valuation of Pichi compared to the non-Equatoguinean sources further above, for it concedes a creative and rejuvenating effect of Pichi lexical influence on Spanish. Such an ambivalence is shared by many members of the country's intellectual elites. On the one hand, falling standards of Spanish are deplored and the widespread use of Pichi in Bioko is seen as a symptom of this decline (see e. g. Bolekia Boleká in Naranjo [2011] and Bolekia Boleká [2005]). On the other hand, many speakers of Pichi, including Equatoguinean intellectuals, also profess their affective links with Pichi, and its role in constituting their identity as Equatoguineans, and inhabitants of Bioko and the capital Malabo (see, for example, Ávila Laurel [2010] and SE [2011]).

This ambivalence is also characteristic of the oral testimonies by Pichi speakers I recorded in Equatorial Guinea. It reflects the balancing act of these speakers between existing language ideologies that disparage the value of Pichi as a language as well as the absence of Pichi in public space, and the positive 
affirmation that speakers experience in their daily use of Pichi as a language of the home, the community and of social interaction. Some of my interlocutors comment on how they were socialized within the family into language use patterns that reflect the lower prestige of Pichi vis-à-vis Spanish. The resulting patterns of domain specialization described in (6) are particularly common in socio-economically more affluent families, who have long-term access to Spanish-medium education:

(6) Bòt yù no, fò wì ya so nà Malabo, bj̀ku fambul dè tok se mek pìkin no tok Pichi nà hos mo, bìkj̀s Pichi notò betà tok. So màma no want hia Pichì nà hos mə. Onlì dèn want hia Pànya.

'But you know, with us here in Malabo, many family members say that children shouldn't speak Pichi at home anymore, because Pichi is not good speech. So the mother doesn't want to hear Pichi in the house anymore. They [the elder family members] only want to hear Spanish. ${ }^{4}$

(Male speaker, in his early 30s)

Spanish is also imposed over Pichi in domains other than caretaker-child interaction, which are equally characterized by status asymmetries, school for example, as explained by the following speaker (7):

(7) Naw à dè tel yù se we wì bìn dè ple bol we wì smol, nà soso Pichì we wì dè tok. Soso Pichì naw we wì dè tok. Wì get son kompìn dèn bìn blant nà Pànya naw, lèk haw dèn kòmət vacación, we dèn dè kan so, wì dè ple bol, nà soso Pichì wì dè tok. Bòt we yù don dè gro, go skul bòku tal, se no, Pichì no fayn.

'Now I tell you, when we used to play football when we were small, it was only Pichi that we were speaking. Only Pichi that we were speaking. We had some friends who lived in Spain, as soon as they left on vacation, when they came here, we'd play football, it was only Pichi we'd speak. But when you're growing up, going to school and all that, it's like no, Pichi is not nice.'

(Male speaker, in his early 30s)

The testimony above also indicates that Pichi remains the language of choice for symmetrical, peer-group interaction outside of the home and the classroom. On the

4 Pichi is a tone language with a high and low tonemes. In the transcription of Pichi utterances, all syllables marked with a grave accent are low-toned, all unmarked syllables are hightoned. 
one hand, such domain specialization, formal and asymmetrical (Spanish) vs. informal and symmetrical (Pichi), reflects the subordinate position of Pichi. On the other hand, the dichotomy also leads speakers to construct an egalitarian view of the language. In contrast to Spanish, Pichi can be mastered without formal education, and thereby serves a much broader cross-section of society than Spanish.

(8) Yù no se bj̀ku pipùl dèn no go skul. Dèn no kan get wan formación. Dì onlì langwèch we dèn dè tok fayn fayn nà Pichì, bikos fò tok Pànya, nà fò go skul. Bj̀t we yù no go skul yù fò tok sòn tin. Fò tok Pichi yù no nid fò go skul. Nà kwatà yù dè tok Pichì. So bj̀ku pipùl fò Nyumbili, Nyumbili nà dì kwatà we po pipùl dèn blant fò fen layf. Wan smol rum wit chapa dan tin.

'You know that many people haven't been to school. They haven't received any professional training. The only language they speak really well is Pichi, because in order to speak Spanish, it's necessary to got to school. But when you haven't been to school you have to speak something. In order to speak Pichi you don't need to go to school. In your area you speak Pichi. So, many people in Nyumbili, Nyumbili is the area where poor people live trying to make a living. A small room with a corrugated iron roof, that kind of thing.'

(Female speaker, in her 40s)

Many speakers also have an acute sense of awareness of the value of Pichi as an international language. This view could not be summarized better than in the following speaker's own words, who counters negative views about Pichi (including its classification as a dialect rather than a language by his relatives from the continental part of the country), by drawing attention to the global reach of English-lexifier creoles like Pichi:

(9) Mi get dan problema wit bəy dèn we dèn kòmət Bàtà nə, se 'no Pichì es un dialecto'. À kìn tel dèn se Pichì fit bad, à se bàt dì tin we dè mek mek tu pipùl dèn kòmıt difren say, dèn dè j̀ndàstan è no fit bi bad tin. À tel dèn se fò go naw naw nà Camerún, à rich, à gò blant, à gò tok mebì French, à gò tok Pichi. À go Nigeria, tok Pichi dèn gò hia, à go Ghana, à go Sierra Leone, Pichì. Yù dè go, yù dè mek àn ples bày ples dèn de tok àn. Nà Trinidad sef no? Trinidad àn Tobago, dèn dè tok Pichi scf.

'I have that problem with the guys from the continent, who go like "no Pichi is a dialect". I usually tell them that Pichi might be bad, but something that makes two people who come from different places understand each other 
can't be something bad. A tell them that if I had to go to Cameroon right now, I arrive, I remain, I might maybe speak French, or I might speak Pichi. If I go to Nigeria, speak Pichi, they'll understand, I go to Ghana, I go to Sierra Leone, it's Pichi. If you go from place to place, it's spoken there. Even in Trinidad, right? Trinidad and Tobago, they even speak Pichi there.'

(Male speaker, in his 20s)

The excerpts presented above reflect the contradictory nature of the values ascribed to Pichi by different social groups and social institutions. Pichi speakers are aware of these contradictions and negotiate them by oscillating between negative and positive valuations of the language in their own discourse and by adhering to particular language use patterns.

The excerpts in this section reflect the operation of the three semiotic processes referred to in Section 2. These processes serve as a means to construct Pichi as different and divergent from the norm. This norm is implicitly or explicitly understood as the European colonial language Spanish, or English, the lexifier of Pichi. The process of recursivity emerges from the opposition between "dialect" (the term employed for the African creole language Pichi) and "language" (the European prestige language Spanish), see (2) and (9) above. The construct is part of a familiar European tradition of discourse, where the label "dialect" has served to oppose sociopolitically subordinated language varieties to superordinate, "national languages” in the context of the development of nationalist ideologies since the eighteenth century (see Blommaert and Verschueren [1998]; also the classic study by Haugen [1966]). In our case, recursivity is the mechanism by which these oppositions are projected into the Equatoguinean context and onto the relation between Pichi and Spanish. In this way, Pichi is not only constructed as inferior to, but also as a threat to Spanish, the orderly and pure, elaborate and standardized counterpart of Pichi.

The representation of Pichi as a localized, substandard form of speech is only possible via the process of erasure. This allows participants and observers of the linguistic scenario of Equatorial Guinea to overlook the fact that Pichi is one of the largest languages of Equatorial Guinea, international in its reach and mutually intelligible with languages spoken by more than 100 million people in West Africa and beyond. By the same process of erasure, the structural complexity and grammatical elaboration of Pichi is overlooked or denied (Yakpo [2009] is a 700-page grammar of the language), as well as the circumstance that the lexicon of Pichi is not substantially more mixed than that of Spanish (cf. Quintana and Mora [2003] for an overview of the Arabic import alone), and certainly less hybrid than that of English, with its substantially mixed lexicon (cf. Finkenstaedt et al. 1970; Thomason and Kaufman 1988: 263-341). In fact, remaining within the trope of endangerment, Spanish, with its prestige and total 
dominance of all socio-linguistic domains in Equatorial Guinea rather poses a serious threat to the integrity of the grammar and lexicon of Pichi. Under the impact of Hispanization and globalization, large parts of the Pichi lexicon relating to traditional culture, the arts, religion, traditional agriculture and medicine, a rich oral literature, as well as the stylistic variation that characterizes the complex social interaction typical of traditional societies are fast falling into oblivion. At the same time code-switching with, and borrowing from Spanish are beginning to transform the typological make-up of Pichi (Yakpo 2009b).

The discourses on Pichi also involve elements of iconization. Most of the few academic sources before Yakpo (2009) containing references to Pichi represent it as a "market” idiom (Quilis 1993: 14) without a discernible native speaker community, used primarily as an "out-group language” (Granda 1985) and in "commercial transactions" (Obediente 2007: 559). For these observers, the cultural heterogeneity and pluralism that characterize the speaker community of Pichi make it difficult to neatly demarcate its "ethnic identity" and this can be seen to directly reflect ideas about the assumed hyper-hybridity of Pichi and its lack of structural order.

By interpreting particular language ideologies about Pichi and the other English Creoles of West Africa, we may therefore come closer to identifying some of the causes of the misalignment between existing language policies and the actual role played by Pichi in Equatoguinean society.

\section{The comparative perspective}

I have attempted to describe, in the preceding sections, sociolinguistic characteristics of the speaker community of Pichi, the domains of use, the degree of politico-legal recognition accorded to it and ideologies about the language. In this section, I compare some of these sociolinguistic characteristics of Pichi with those of other English-lexicon creoles of West Africa. The comparative perspective allows us to identify the specificities of the sociolinguistic situation of Pichi vis-à-vis its sister language in West Africa. A broader perspective also enables us to arrive at further conclusions about the role of language ideologies in the linguistic ecology of Equatorial Guinea.

Table 1 below summarizes the characteristics of Pichi, and those of the four largest English-lexicon creoles of West Africa Nigerian Pidgin (80 million speakers, cf. Ihemere [2006]), Cameroon Pidgin (10 million speakers, cf. Lewis et al. [2013]), Krio (Sierra Leone, 6 million speakers, cf. Finney [2013]), and Ghanaian Pidgin (5 million speakers, cf. Huber [2013]). 
Table 1: Comparison of selected socio-linguistic characteristics of West African English-lexicon creoles.

\begin{tabular}{|c|c|c|c|c|c|c|c|}
\hline & Context & Characteristic & Pichi & $\begin{array}{r}\text { Ghanaian } \\
\text { Pidgin }\end{array}$ & $\begin{array}{r}\text { Cameroon } \\
\text { Pidgin }\end{array}$ & $\begin{array}{r}\text { Nigerian } \\
\text { Pidgin }\end{array}$ & Krio \\
\hline \multirow[t]{5}{*}{ a. } & \multirow{5}{*}{$\begin{array}{l}\text { Speaker } \\
\text { community }\end{array}$} & L1 community & $\checkmark$ & $x$ & $v$ & $\mathrm{v}$ & $\mathrm{v}$ \\
\hline & & More L2 than L1 speakers & $\checkmark$ & v & V & V & $\sqrt{ }$ \\
\hline & & $\begin{array}{l}\text { Ethnic community } \\
\text { language }\end{array}$ & $\checkmark$ & $x$ & $\mathrm{~V} / \times$ & $\mathrm{V} / \times$ & $\checkmark$ \\
\hline & & Use as a lingua franca & V & $x$ & $\checkmark$ & $\checkmark$ & $\checkmark$ \\
\hline & & $\begin{array}{l}\text { Proportion of (L1 \& L2) } \\
\text { speakers over total } \\
\text { population (\%) }\end{array}$ & $\sim 15$ & $\sim 20$ & $\sim 40$ & $\sim 50$ & $\sim 95$ \\
\hline \multirow[t]{5}{*}{ b. } & \multirow{5}{*}{$\begin{array}{l}\text { Status } \\
\text { planning } \\
\& \text { corpus work }\end{array}$} & Legal recognition & $x$ & $x$ & $x$ & $x$ & $\checkmark$ \\
\hline & & Standard orthography & $x$ & $x$ & $x$ & $x$ & $\checkmark$ \\
\hline & & Medium of instruction & $x$ & $x$ & $x$ & $x$ & $x$ \\
\hline & & School subject & $x$ & $x$ & $x$ & $x$ & $\checkmark$ \\
\hline & & Description & $\checkmark$ & $\checkmark$ & $\checkmark$ & $\checkmark$ & $\checkmark$ \\
\hline \multirow[t]{7}{*}{ c. } & Domains of use & Creative literature & $x$ & $x$ & $\mathrm{~V} / \times$ & $V / x$ & $\checkmark$ \\
\hline & & Religion, written \& oral & $x$ & $x$ & V & v & $\checkmark$ \\
\hline & & $\begin{array}{l}\text { Civic education, literacy } \\
\text { campaigns }\end{array}$ & $x$ & $x$ & $\checkmark$ & $\checkmark$ & $\checkmark$ \\
\hline & & Political campaigning & $\times$ & $x$ & $\checkmark$ & $\checkmark$ & $\checkmark$ \\
\hline & & TV/Radio broadcasting & $x$ & $x$ & $\checkmark$ & $\checkmark$ & $\sqrt{ }$ \\
\hline & & Pop music & $x$ & 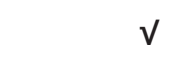 & $\checkmark$ & $\checkmark$ & $\sqrt{ }$ \\
\hline & & Advertising & $x$ & $\checkmark$ & $\checkmark$ & $\checkmark$ & $\checkmark$ \\
\hline
\end{tabular}

The order of languages in Table 1 reflects the spectrum of uses and the relative status of the five largest West African English-lexicon creoles. Krio on the very right features the largest proportion of speakers (95 percent of the population of Sierra Leone is estimated to speak Krio, see Finney [2013: 157]). Krio has also conquered the largest number of use domains of all English-lexicon creoles and has been the subject of status and corpus planning to a higher degree than the other languages. Research on Krio extends to socio-historical and descriptive work (e. g. Berry [1961]; Jones [1968]; Hancock [1971] for some earlier works), and the most extensive dictionary of an African English-lexicon creole to date (Fyle and Jones 1980). Krio has a higher prestige than the other African Englishlexicon creoles, has seen some degree of official recognition and has been the subject of policy-making, as shown in the fact that is the only English-lexicon creole to be a school subject. Even if modest in dimension. Krio is also more 
widely used than other African English-lexicon creoles as a written medium both in secular (e.g. Decker 1988) and religious writing (e.g. Bible Society in Sierra Leone 2013), and with a more widely accepted orthography (see Coomber 1992).

Nigerian Pidgin and Cameroon Pidgin fall into the middle range of the spectrum. The overall sociolinguistic situation of these two languages is very similar. The proportion of L1 cum L2 speakers is significantly lower than that of Krio but still substantial. Both are probably spoken by a larger percentage of people in their respective homelands than any other African language (for Nigeria, see Adegbija [2004: 226] and Faraclas [2013: 176]; for Cameroon, see Mbangwana [1983] and Schröder [2003: 82-86]). Neither in Cameroon nor Nigeria have the two languages enjoyed any legal recognition nor any other serious attempt at status and corpus planning (for Nigeria, see Agheyisi [1988] and Igboanusi [2008]). As a consequence, Nigerian Pidgin is the only large Nigerian language to yet have no officially recognized orthography (Ojarikre 2013). Descriptive and standardizing efforts vis-à-vis the two languages have been limited to academic work (cf. in particular Todd [1969, 1991], Todd and Jumbam [1992], de Feral [1978, 1989] and Kouega [2008], which is the most comprehensive dictionary of the language), as well as Christian proselytization (for Cameroon, e. g. Molindo [1996]; for Nigeria, e. g. http://nigerianpidgin-bible. yolasite.com) even if Nigerian Pidgin has been used in some short-lived grassroots literacy campaigns (e. g. Faraclas 1986). On a whole, Nigerian Pidgin and Cameroon Pidgin have made their farthest advances into additional domains through their use in oral genres like pop music, film, comedy, radio programming, and advertising (for Cameroon, see Schröder [2003: 123-125] and Anchimbe [2013: 172-173]; for Nigeria, see Deuber [2005: 53]). These advances have been championed by the youth in Cameroon and Nigeria and by the appropriation of both languages as languages of self-identification and counter-culture in homes, neighborhoods, schools and on university campuses (cf. Schröder 2003: 181; Deuber 2005: 51; Anchimbe 2013: 179-187).

Ghanaian Pidgin occupies an intermediate position between Nigerian Pidgin and Cameroon Pidgin on the one hand, and Pichi on the other with respect to its sociolinguistic situation. Contrary to all other English-lexicon creoles listed in Table 1, Ghanaian Pidgin is a language without L1 speakers (Huber 1995), it is therefore the only true pidgin among the languages listed. A variety of Ghanaian Pidgin English referred to in the literature as "Student Pidgin" (Dako 1999, 2002) has become the dominant lect of Ghanaian Pidgin. This variety emerged through use in secondary schools and on university campuses in the decades after Ghana's independence (Bannerman 1996, 2006; Dako 2002), and has developed into a youth sociolect for males in particular (Dako 1999, 2002). Ghanaians can 
resort to other languages as lingua francas, i. e. Standard (Ghanaian) English and Akan. "Student Pidgin" therefore exclusively serves the function of selfidentification (for an example of use in contemporary Ghanaian pop music, see the works of the Ghanaian Hip Hop band Fokn Bois, http://youtu.be/R_ YsQK2Yo3c). This characteristic once more sets Ghanaian Pidgin sharply apart from the other English-lexicon creoles covered in this section. The lack of any institutionally driven form of status or corpus planning that transpires from section (b) of Table 1, and its dominant function as a youth sociolect rather than a community's L1 therefore represents far less of a misalignment with the lack of an official status quo than is the case with the other languages with their large native speaker communities.

In comparison to its sister languages, Pichi can be considered the most disadvantaged English creole in West Africa on all counts. All English creoles of West Africa to some extent suffer from a low socio-economic prestige (cf e.g. Deuber [2005: 50-51] for Nigerian Pidgin; Mallah [2003] for Cameroon Pidgin). However, the most striking aspect of the marginalization of Pichi compared to its sister languages is its conspicuous absence from unregulated domains such as pop music, advertising and (private) broadcasting, domains in which the other West African creoles and pidgins have made their greatest advances. Even Ghanaian Pidgin, which is neither used as an L1, like Pichi, nor even as a lingua franca, surpasses Pichi in the number of domains in which it is used. I conclude that negative views about Pichi, which transpire in the language ideologies that I have sought to identify in Section 4.2, are an important cause and simultaneously a reflection of the present status quo of Pichi.

However, Equatorial Guinea also stands out from the other African countries covered in this article in the general absence of an organized state response to linguistic diversity within its borders. Equatorial Guinea probably has the most profoundly exoglossic language policy of these countries, with a total reliance on the colonial language Spanish in all but the most informal domains. This general characteristic is reflected in the linguistic scenario, where Pichi is the most unequal among unequals, when compared to the creoles spoken in the other African nations.

\section{Conclusion}

The absence of, or negative nature of state responses to English creoles and pidgins is the consequence of a complex constellation of economic and political factors that other African languages are also subjected to. However, in all the countries covered in Section 5, ideological factors have played a 
disproportionately large role in consolidating lingering colonialist attitudes about the unfitness of the English creoles to serve as mediums of communication in high prestige domains beyond the home, the marketplace or popular culture.

In spite of the lack of state support in all these countries, the utility of the English-lexifier creoles of West Africa for national and international communication have however led to them increasingly penetrating domains formerly reserved to the colonial language. Besides the practical value of these languages, an additional reason for this development is an ongoing ideological shift vis-à-vis the creoles. My observation is that the English creoles and pidgins of Sierra Leone, Nigeria, Cameroon and Ghana can count on the growing support and allegiance of the younger generations. To these, the creoles and pidgins serve as means of self-identification and self-expression. One likely cause among others for the increasing acceptance of these languages in the public sphere is the increasing temporal distance from British colonial rule and consequently, a greater intellectual and cultural independence of the members of the economic and political elites of these countries.

In contrast, Equatorial Guinea, with its enduring orientation towards Spain, and its rather specific political and economic trajectory in the last decades has remained relatively isolated from these regional developments. As a consequence, developments with respect to Pichi, and in fact with respect to the other African languages of Equatorial Guinea, are lagging behind in comparison to the other four countries discussed in Section 5. Further research is needed in order to determine how in the specific case of Equatorial Guinea, language ideologies concretely impact political and institutional decision-making on language by the political and cultural elites of the country. In the meantime, Pichi is likely to continue expanding its social functions by gradual, self-propelled growth, as has been the case with the English-lexifier creoles and pidgins of Cameroon, Nigeria, Ghana, and Sierra Leone.

\section{References}

Aboh, Enoch Oladé \& Norval Smith. 2009. Complex processes in new languages. Amsterdam: John Benjamins. (accessed 24 October 2012).

Adegbija, Efurosibina. 2004. Language policy and planning in Nigeria. Current Issues in Language Planning 5(3). 181-246.

Agheyisi, Rebecca Nogieru. 1988. The standardization of Nigerian Pidgin English. English world-wide 9(2). 227-241.

Anchimbe, Eric A. 2013. Language policy and identity construction: The dynamics of Cameroon's multilingualism. Amsterdam: John Benjamins Publishing. 
Ansaldo, Umberto, Stephen Matthews \& Lisa Lim (eds.). 2007. Deconstructing creole. Amsterdam: John Benjamins.

Asociación Cristiana de Traducciones Biblicas. n.d. Kálara Nzamá Fan Guinea Ecuatorial. Bata: n.p. Ávila Laurel, Juan Tomás. 2010. Guinea siempre one. Digital magazine. Fronterad, Revista Digital. http://www.fronterad.com/?q=bitacoras/juanavila/guinea-siempre-one (accessed 9 November 2014).

Bakker, Peter, Aymeric Daval-Markussen, Mikael Parkvall \& Ingo Plag. 2011. Creoles are typologically distinct from non-creoles. Journal of Pidgin and Creole Languages 26(1). 5-42.

Baldauf, Richard B \& Robert B Kaplan. 2004. Language planning and policy in Africa, vol.1. Clevedon: Multilingual Matters.

Baldauf, Richard B \& Robert B Kaplan. 2007. Language planning and policy in Africa, vol. 2. Clevedon: Multilingual Matters.

Bamgbose, Ayo. 2000. Language and exclusion: The consequences of language policies in Africa. Münster: Lit Verlag Global.

Bannerman, Forson E. 1996. An investigation into the Argot (pidgin) as a means of communication among students in Ghanaian secondary schools. University of Ghana, Legon Mphil thesis.

Bannerman, Forson E. 2006. Student pidgin English (SPE): A Ghanaian English in Vitro. University of Ghana, Legon PhD thesis.

Berry, Jack. 1961. English loanwords and adaptations in Sierra Leone Krio. In Robert B. Le Page (ed.), Creole language studies II, 1-16. London: Macmillan.

Bible Society in Sierra Leone. 2013. Krio fos oli Baybul.

Bickerton, Derek. 1981. Roots of language. Ann Arbor: Karoma Publishers.

Bickerton, Derek. 1984. The language bioprogram hypothesis. Behavioral and Brain Sciences 7(02). 173-188.

Blommaert, Jan \& Jef Verschueren. 1998. The role of language in European nationalist ideologies. In Bambi B. Schieffelin, Kathryn A. Woolard \& Paul V Kroskrity (eds.), Language ideologies: Practice and theory, 189-210. New York: Oxford University Press.

Bolekia Boleká, Justo. 2005. Panorama de la literatura en español en Guinea Ecuatorial. El español en el mundo. (Anuario del Instituto Cervantes). Instituto Cervantes. http://cvc. cervantes.es/lengua/anuario/anuario_05/bolekia/p01.htm (accessed 11 August 2014).

Brock-Utne, B. 2010. Research and policy on the language of instruction issue in Africa. International Journal of Educational Development 30(6). 636-645.

Brock-Utne, Birgit. 2001. Education for all - in whose language? Oxford Review of Education 27(1). 115-134.

Brock-Utne, Birgit. 2003. The language question in Africa in the light of globalisation, social justice and democracy. International Journal of Peace Studies. 67-87.

Castillo Rodriguez, Susana. 2013. Language and the hispanization of Equatorial Guinea. In José Del Valle (ed.), A political history of Spanish: The making of a language, 350-. Cambridge University Press.

Coelho, A. 1967. Os dialectos românicos ou neolatinos na África, Ásia e América. Novas notas complementares. In Jorge Morais-Barbosa (ed.), Estudos Linguísticos Crioulos, 1-234. Lisboa: Academia International da Cultura Portuguesa.

Coomber, Ajayi. 1992. The new Krio orthography and some unresolved problems. In Eldred D. Jones, Karl I. Sandred \& Neville Shrimpton (eds.), Reading and writing Krio, 15-20. Uppsala: Acta Universitatis Upsaliensis. 
Dako, Kari. 1999. Pidgin as a gender-specific language in Ghana. Ghanaian Journal of English Studies 1. 73-81.

Dako, Kari. 2002. Student pidgin (SP): The language of the educated male elite. Research review from the Inst. of African Studies (IAS), Univ. of Ghana 18(2). 53-62.

Decker, Thomas. 1988. Juliohs Siza (Krio Publications Series). Umeå: Umeå University.

DeGraff, Michel. 2003. Against creole exceptionalism. Language 79(2). 391-410.

Deuber, Dagmar. 2005. Nigerian pidgin in lagos: Language contact, variation and change in an African urban setting. London: Battlebridge.

Devonish, Hubert. 1986. Language and liberation: Creole language politics in the Caribbean. London: Karia Press.

Devonish, Hubert. 2010. The language heritage of the Caribbean: Linguistic genocide and resistance. Glossa 5(1). 1-26.

Djité, Paulin G. 2008. The sociolinguistics of development in Africa. Clevedon \& Buffalo: Multilingual Matters.

Faraclas, Nicholas G. 2013. Nigerian Pidgin. In Susanne Michaelis, Philippe Maurer, Martin Haspelmath \& Magnus Huber (eds.), The atlas of Pidgin and Creole language structures: English-based and Dutch-based languages, 1. 176-184. Oxford: Oxford University Press. http://lingweb.eva.mpg.de/apics (22 December, 2015).

Faraclas, Nicholas Gregory. 1986. Reading and writing Nigerian pidgin. Port Harcourt: Rivers Readers Project (RRP).

Faraclas, Nicholas \& Thomas B. Klein. 2009. Simplicity and complexity in creoles and pidgins. London: Battlebridge.

Féral, Carole de. 1989. Pidgin-English du Cameroun: Description linguistique et sociolinguistique, 5. (Sociolinguistique). Paris: Peeters/SELAF.

Féral, Carole de. 1978. Le pidgin English au Cameroun. In Daniel Barreteau (ed.), Inventaire des Études Linguistiques sur les Pays d'Afrique Noire d'Expression Française et sur Madagascar, 351-356. Paris: SELAF.

Finkenstaedt, Thomas, Ernst Leisi \& Dieter Wolff. 1970. A chronological English Dictionary: Listing 80000 words in order of their earliest known occurrence. Heidelberg: Carl Winter.

Finney, Malcolm Awadajin. 2013. Krio. In Susanne Michaelis, Philippe Maurer, Martin Haspelmath \& Magnus Huber (eds.), The atlas of pidgin and creole language structures: English-based and Dutch-based languages, vol.1, 157-166. Oxford: Oxford University Press. http://lingweb.eva.mpg.de/apics.

Fyle, Clifford N. \& Eldred D. Jones. 1980. A Krio-English Dictionary. Oxford \& New York: Oxford University Press.

Gal, Susan \& Judith T. Irvine. 1995. The boundaries of languages and disciplines: How ideologies construct difference. Social Research 62(4). 967-1001.

Granda, Gérman de. 1985. Préstamos léxicos del pidgin English en el criollo portugués de Annobón. Estudios Románicos (1). 101-112.

Hancock, Ian F. 1971. A study of the sources and development of the lexicon of Sierra Leone Krio. PhD dissertation, University of London.

Haugen, Einar. 1966. Dialect, language, nation. American Anthropologist 68(4). 922-935.

Huber, Magnus. 1995. Ghanaian pidgin English: An overview. English World-Wide 16(2). 215-249.

Huber, Magnus. 2013. Ghanaian pidgin English. In Susanne Michaelis, Philippe Maurer, Martin Haspelmath \& Magnus Huber (eds.), The atlas of pidgin and creole language structures: 
English-based and Dutch-based languages, vol.1, 167-175. Oxford: Oxford University Press. http://lingweb.eva.mpg.de/apics.

Igboanusi, Herbert. 2008. Empowering Nigerian pidgin: A challenge for status planning? World Englishes 27(1). 68-82. doi:10.1111/j.1467-971X.2008.00536.x (accessed 2 April 2014).

Ihemere, Kelechukwu Uchechukwu. 2006. A basic description and analytic treatment of noun clauses in Nigerian pidgin. Nordic Journal of African Studies 15(3). 296-313.

Irvine, Judith T. 1989. Strategies of status manipulation in Wolof greetings. In Richard Bauman \& Joel Sherzer (eds.), Explorations in the ethnography of speaking, 167-191. Cambridge \& New York: Cambridge University Press. http://dx.doi.org/10.1017/СB09780511611810 (accessed 29 May 2013).

Irvine, Judith T \& Susan Gal. 2000. Language ideology and linguistic differentiation. In Paul V. Kroskrity (ed.), Regimes of language: Ideologies, polities, and identities, 35-83. Oxford:

J. Currey.

Jones, Eldred D. 1968. Some tense, mode and aspects markers in Krio. African Language Review 7. 86-89.

Kamwangamalu, Nkonko M. 2004. The language policy/language economics interface and mother-tongue education in post-apartheid South Africa. Language Problems \& Language Planning 28(2). 131-146.

Kouega, Jean-Paul. 2008. A dictionary of Cameroon pidgin English usage: Pronunciation, grammar and vocabulary (LINCOM Studies in pidgin \& Creole Linguistics 9). München: Lincom Europa.

Lewis, M. Paul, Gary F. Simons \& Fennig (eds.). 2013. Ethnologue: Languages of the world. Dallas, TX: SIL International. http://www.ethnologue.com (accessed 30 May 2013).

Lipski, John M. 1992. Pidgin English Usage in Equatorial Guinea (Fernando Poo). English World-Wide 13(1). 33-57.

Lynn, Martin. 1984. Commerce, Christianity and the origins of the "Creoles" of Fernando Po. The Journal of African History 25(3). 257-278.

Makoni, Sinfree \& Alastair Pennycook. 2007. Disinventing and reconstituting languages, vol. 62. (Bilingual Education and Bilingualism). Clevedon: Multilingual Matters.

Mallah, Marie-Louise Njong G.. 2003. Language stigmatization: The case of Cameroonian pidgin English. PhD dissertation, National University of Singapur.

Mbangwana, Paul. 1983. The scope and role of pidgin English in Cameroon. In Edna L. Koenig, Emmanuel Nges Chia \& John F. Povey(eds.), A sociolinguistic profile of urban centers in Cameroon, 79-92. Los Angeles: Crossroad Press.

McWhorter, John. 2001. The world's simplest grammars are creole grammars. Linguistic Typology 5(3/4). 125-156.

McWhorter, John H. 2005. Defining creole. New York, NY: Oxford University Press.

Molindo, Ekoka A. 1996. Cameroon pidgin Bible. http://molindo.nple.com (accessed 4 February 2014).

Morgades Bessari, Trinidad. 2004. El español en Guinea Ecuatorial. Rosario, Argentina: Instituto Cervantes.

Morgades Bessari, Trinidad. 2011. Los criollos (Fernandinos-Kriös) de Guinea Ecuatorial. La Gaceta de Guinea Ecuatorial. Malabo, Equatorial Guinea, No.162 edition, sec. Misceláneas. http://www.lagacetadeguinea.com/162/19.htm (accessed 30 May 2013). Mudimbe, Valentin Y. 1988. The invention of Africa: Gnosis, philosophy, and the order of knowledge. Bloomington: Indiana University Press. 
Muthwii, Margaret Jepkirui \& Angelina Nduku Kioko (eds.). 2004. New language bearings in Africa: A fresh quest. Buffalo, NY: Multilingual Matters.

Mwinsheikhe, Halima Mohammed. 2002. Education in Africa. Using Kiswahili as a medium of instruction in Tanzania secondary schools as a strategy of improving student participation and performance in science. Oslo: Universitetet i Oslo.

Naranjo, José. 2011. El español agoniza en Guinea Ecuatorial. GuinGuinBali, una ventana a África. Las Palmas de Gran Canaria. http://www.guinguinbali.com/index.php?lang= es\&mod=news\&cat=4\&id=2424 (accessed 8 November 2014).

Obediente, Enrique. 2007. Biografía de una lengua: nacimiento, desarrollo y expansión del español. Mérida, Venezuela: Universidad Los Andes.

Ojarikre, Anthony. 2013. Perspectives and problems of codifying Nigerian pidgin English orthography. Developing Country Studies 3(12). 126-133. (accessed 2 April 2014).

Olo Fernandes, Lucas. 2012. Apropiación de la educación en Guinea Ecuatorial y Lenguas Nacionales. Manuscript. Barcelona, ms.

Organisation internationale de la francophonie. 2010. La langue française dans le monde. Paris: Editions Nathan. http://www.francophonie.org/IMG/pdf/Synthese-LangueFrancaise-2010.pdf (accessed 30 May 2013).

Ouane, Adama \& Christine Glanz. 2010. Why and how Africa should invest in African languages and multilingual education: An evidence-and practice-based policy advocacy brief. ERIC. http://files.eric.ed.gov/fulltext/ED540509.pdf (accessed 8 November 2014).

Perrois, L. 1972. La statuaire fang, Gabon.

Piedrafita, Belén. 2009. Agustín Nze: «En Guinea Ecuatorial el español es innegociable». FundéuBBVA, Fundación del español urgente. Madrid. http://www.fundeu.es/noticia/agustinnze-en-guinea-ecuatorial-el-espanol-es-innegociable-2613/ (accessed 10 November 2014).

Plag, Ingo (ed.). 2003. Phonology and morphology of creole languages. (Linguistische Arbeiten 478). Tübingen: Niemeyer.

Prah, Kwesi Kwaa. 2002. Rehabilitating African languages: Language use, language policy and literacy in Africa: Selected case studies. Cape Town, South Africa: Centre for Advanced Studies of African Society (CASAS).

Quilis, Antonio. 1993. La lengua española en Filipinas y en Guinea Ecuatorial. Boletín Informativo de la Fundación Juan March. (La Lengua Española, Hoy). 3-16.

Quintana, Lucía \& Juan PabloMora. 2003. Enseñanza del acervo léxico árabe de la lengua española. In Manuel Pérez Gutiérrez \& José Coloma Maestre (eds.), El español, lengua del mestizaje y la interculturalidad, vol. XIII. (Actas de ASELE). Madrid: Instituto Cervantes. http://cvc.cervantes. es/ensenanza/biblioteca_ele/asele/pdf/13/13_0697.pdf (accessed 29 May, 2013).

Reh, Mechthild \& Bernd Heine. 1982. Sprachpolitik in Afrika. Hamburg: Helmut Buske Verlag.

República de Guinea Ecuatorial. 2007. Ley Núm. 5/2.007. Ley general de educación.

Schieffelin, Bambi B. \& Rachelle Charlier Doucet. 1994. The "real" Haitian creole: Ideology, metalinguistics, and orthographic choice. American Ethnologist 21(1). 176-200.

Schröder, Anne. 2003. Status, functions, and prospects of pidgin English: An empirical approach to language dynamics in Cameroon. Tübingen: Gunter Narr Verlag.

SE. 2011. Cronica de una reunión imposible. El Confidencial de Guinea Ecuatorial. http:// geconfidencial.blogspot.hk/2011/04/cronica-de-una-una-reunion-imposible.html (accessed 10 November 2014).

Skutnabb-Kangas, Tove, Robert Phillipson \& Mart Rannut (eds.). 1994. Linguistic human rights: Overcoming linguistic discrimination. (Contributions to the Sociology of Language 67). Berlin; New York: Mouton de Gruyter. 
Thomason, Sarah G. \& Terrence Kaufman. 1988. Language Contact, Creolization, and Genetic Linguistics. Berkeley \& Los Angeles: University of California Press.

Tiogang, Issacar Nguen Djo. 2007. La creación semántica y léxica en el español de Guinea Ecuatorial. PhD dissertation, Unversidad Complutense de Madrid.

Todd, Loreto. 1969. Pidgin English of West Cameroon. Camelang 1. 35-57.

Todd, Loreto. 1991. Talk pidgin: A structured course in West African pidgin English. Leeds: Tortoise Books.

Todd, Loreto \& Martin Jumbam. 1992. Kamtok: Anatomy of a pidgin. English Today 8(01). 3-11. Whinnom, Keith. 1971. Linguistic hybridization and the "special case" of pidgin and creoles. In Dell Hymes (ed.), Pidginization and creolization of languages, 91-115. Cambridge: Cambridge University Press.

Yakpo, Kofi. 2009a. A Grammar of Pichi. PhD dissertation, Radboud University Nijmegen. http://hdl.handle.net/2066/79407 (19 November, 2015).

Yakpo, Kofi. 2009b. Complexity revisited: Pichi (Equatorial Guinea) and Spanish in contact. In Nicholas G. Faraclas \& Thomas Klein (eds.), Simplicity and complexity in creoles and pidgins, 183-215. London: Battlebridge.

Yakpo, Kofi. 2010. Gramática del Pichi. (Laboratorio de recursos orales 13). Barcelona: CEIBA.

Yakpo, Kofi. 2011. Lenguas de Guinea Ecuatorial: de la documentación a la implementación. Oráfrica 7. 13-28.

Yakpo, Kofi. 2012. Reiteration in Pichi: Forms, Functions and Areal-Typological Perspectives. In Enoch A Aboh \& Anne Zribi-Hertz (eds.), The morphosyntax of reiteration in creole and non-creole languages, 43. 251-284. Creole Language Library. Amsterdam: John Benjamins.

Yakpo, Kofi. 2013. Pichi. In Susanne Michaelis, Philippe Maurer, Martin Haspelmath \& Magnus Huber (eds.), The atlas of Pidgin and creole language structures: English-based and Dutchbased languages, vol. 1, 194-205. Oxford: Oxford University Press. http://lingweb.eva. mpg.de/apics.

Yakpo, Kofi. 2013a. Wayward Daughter: Language Contact in the Emergence of Pichi (Equatorial Guinea). Journal of African Languages and Linguistics 34(2). 275-299. doi:10.1515/jall-2013-0009.

Yakpo, Kofi. 2013b. Pichi. In Susanne Michaelis, Philippe Maurer, Martin Haspelmath \& Magnus Huber (eds.), The atlas of Pidgin and Creole language structures: English-based and Dutch-based languages, 1. 194-205. Oxford: Oxford University Press. http://lingweb.eva. mpg.de/apics (16 December, 2015).

Zarco, Mariano de. 1938. Dialecto inglés-africano o Broken-English de la colonia española del Golfo de Guinea. Turnhout, Belgium: H. Proost. 